\title{
Art Time City on the temporality of urban interventions
}

On the 27-29 May 2016, in Barreiro, an historical municipality on Lisbon's margem sul, an event associated to DINÂMIA'CET-IUL's project ARTSBANK took place: Contemporaneidades do Espaço Industrial. This threeday long occupation of the former CIN dye factory included artistic interventions, exhibitions, projections, walks, discussions and debates, with the aim to explore and test the potentialities of the ephemeral reuse of abandoned industrial spaces. On the first day we organized the workshop: ART TIME CITY, on the temporality of urban intervention. ${ }^{1}$

Situated in this transient space par excellence, amid the scars and ruins of Barreiro's glorious industrial past, in a former factory whose walls, appropriately adorned by Vhils' sibylline graffiti ${ }^{2}$, a gesture towards the blurred shapes of an undefined future, the workshop could not be better positioned to discuss the complexity of temporality, as a key dimension in which the relation between art and the city occurs. A dimension, that even amid the contemporary surge of interest vis-à-vis urban interventions, still remains widely overlooked.

If public art is typically driven by the urge to freeze historical events into a permanent form (most notably, the monument), urban interventions play with notions of transience, ephemerality and event, usually lasting only a limited amount of time before being altered, put to other uses, or obliterated. On one side, this involves radically different temporalities vis-à-vis the process of artistic production and actualization, towards contingent, relational and eventful praxis. On the other, this singles out the key question of how to prolong the 'duration' of the intervention (its effect and impact) beyond the fleeting contingency of its occurrence, or how to make 'permanent' its products and, not secondarily, whether this is desirable at all.

The contradictory interplay between transience and prolongation, the event and its resonance, is undeniably the crucial question of urban intervention, whose force resides 'in its capacity to resist disappearance' in the face of its necessarily ephemeral actualization ${ }^{3}$. A question potentially addressed via the memorializing and sharing potential of digital and social media, although only partially so. A question, moreover, that urban interventions share with neoliberal urbanism, whose temporal logic is framed by a strategic concern with plugging urban space into long-term growth processes via transient events. 'Eventification' is the term coined by Doreen Jacob to indicate such short-termist obsession with events characterizing the contemporary city ${ }^{4}$. From pop-up shops to mega events, notions and tactics such as temporary uses or autonomous zones, increasingly migrate from the realm of artistic avant-gardes and activism into the toolbox of neoliberal ideology, employed as effective ways to champion quick-fix solutions that capitalize on precariousness and insecurity, rather than tackling their causes. ${ }^{5}$

What theoretical framework can help grasping the temporal relations between art and the city that urban interventions enact? What are the aesthetic and political potentials of the ephemeral for artistic practice, what are the risks? How (and if) can the difference between the temporal logics of urban intervention and the rhythm of neoliberal urbanism be maintained? These were among the questions the workshop asked the artists, academics and activists that took part. This special dossier presents five contributions, constituting some of the compelling interventions that took place during the day.

\footnotetext{
${ }^{1}$ Putting aside complex debates over definitions, the workshop assumed 'urban intervention' as a term encompassing different ways to intervene on the city by employing the urban itself (its built environment, social relations, normativities, sites, publicness etc.) as an expressive material.

${ }^{2}$ Vhils is a local, world-renown graffiti artist. Among some of his graffiti we found on the walls of the CIN factory, three words had been sculpted through the bricks: utopia, dystopia, chaos.

Guillame Désanges (2007) "Art in public spaces: Space, Time, Ethics, Passion", Mouvement [English Text], http://guillaumedesanges.com/spip.php?article43.

${ }^{4}$ Doreen Jacob (2013) "The eventification of place: Urban development and experience consumption in Berlin and New York City" 20 European Urban and Regional Studies 4, 447-459.

${ }^{5}$ Mara Ferreri (2015), "The seductions of temporary urbanism", 15 ephemera. theory \& politics in organisation 1, 181-191.
} 
We begin with Ricardo Campos, whose elegant text sets the context for the rest of the dossier, through a compelling reflection on the space and time of graffiti, a practice suspended between cumbersome dichotomies (gallery-street, vandalism-art, communication-disruption, tag-image, legal-illegal) that, useful to discuss the phenomenon, often appear far too rigid to understand it. One may ask whether it is indeed time what graffiti are made of. It is the trace of a fleeting time we read on the illegal tag rapidly drawn by the writer, the crystallization of a hurried adrenalinic gesture performed under the normative tension of a law in the process of being breached, as well as the determination to make a territorial claim, to be transiently expressed, and unlikely to last (though, Campos explains, digital images increasingly allow works to obtain a virtual, as well as paradoxically ephemeral, we may say, eternity). Conversely, in the carefully crafted image of a commissioned graffiti we may read the calm of an unhurried gesture, together with, perhaps, the unexpressed hope that the work be preserved in time. These are among the themes touched upon in Campos' contribution, that provides a valuable conceptual toolbox to explore the intersection between the space-time of graffiti - in their production and duration -, and the tumultuous temporality of neoliberal urbanization.

It is this very intersection that Marta Traquino explores in her text, where she engages with Agnes Denes' famous 1982 Manhattan intervention titled: Wheatfield - A confrontation, and its 2015 'reactivation' by the artist herself in Milan. The eventful contingency of an urban intervention, its imbrication with the complex materiality of the urban space, the structure of its relation with its socio-political context... Such key questions emerge from Traquino's compelling analysis. The wheat field that Denes originally planted in Manhattan opened a space in which, for a given time, the relentless process of urban land valorization was to run idle. At least in this plot, the rhythm of wealth growth was slowed down to the cosmic temporality of wheat growth. This physical and conceptual disruptive value, Traquino observes, is fully lost in Milan, where the wheat field becomes fully integrated within one of Europe's greater gentrification processes, as well as a visual signatures to the Milan 2015 Expo. In this mega-event, explicitly dedicated to the global question of food, the ecological undertone the original work expressed now shares the table with the glaring propaganda of McDonald's, Coca Cola and the other official sponsors of the Expo. The detournement is complete: a depoliticization well expressed by the new title of the work, from which the subtitle a confrontation has been conveniently removed.

As events gradually become a central strategy of neoliberal urbanization, also small, local organizations increasingly resort to them as a way to gather individuals and concentrate meaningful and affective energy to convey messages and pursue socio-cultural objectives. Also based in Milan, the contribution of Sebastiano Citroni looks at cultural events and their use by local non-profit organizations to promote social inclusion. On the bulk of an extensive ethnographic study of forty-eight events organied by ten non-profit organizations between 2007 and 2010, Citroni investigates the potentials and limits of the temporality of urban events vis-à-vis their capacity to achieve the desired effects. Too often, he observes, organizers and researchers alike focus on the before and after phases of the event. In this way the peculiar time of the event, that is, what occurs during its contingent and performative taking place, remains overlooked, or taken for granted, as a negligible syncope between the planning of the event and its hoped-for legacy. Showing the strategic centrality of this phase, Citroni proposes a conceptual and methodological approach attuned to the event's contingency, together with a useful typology whereby exploring events transversally, according to the spatio-temporal phases of their unfolding, as a valuable alternative to the tendency to essentialize them into a-temporal categories (e.g. community-event, spectacle-event, etc.)

In direct relation with the questions raised by Citroni's text, we then move to the contribution of Luisa Alpalhão centred on three urban interventions organized by the atelier urban nomads, an artistic and architectural platform founded by herself. Taking us through a participatory realization of street furniture with reclaimed materials in Alfama, Lisbon; a 100-people long dining table in Fukuoka, Japan; a mobile playground in Marvila, Lisbon; Alpalhão describes the unfolding of these interventions and analyses their outcome, critically exploring them vis$\grave{a}$-vis notions of participation, event and legacy, through the lenses of time. An extended temporality appears as crucial, she argues, whether participation is to be turned from the empty buzzword of social policies it is today, to a real, tangible and long-lasting outcome. Likewise, and "despite the value of ephemeral" and the fascination with event-based strategies, "a slow approach to time" appears to be crucial, she writes, to stretch an event into long-term legacies. Through her text a common refrain thus seems to emerge: as social and artistic projects, as 
well as our lives more generally, are increasingly forced into the frenetic rhythm of contemporary capitalism and its constant requirement to make time productive, perhaps a possible way to resist and build alternatives resides in carving spaces where a simple, wasted, empty and even dead time be allowed to slowly grow, just as a wheat field, among the skyscrapers of Manhattan.

The special dossier ends with the contribution of Rui Mourão, who provides a detailed narration of the controversial intervention he carried out at the Museu do Chiado, in Lisbon. In this 'artivist performance', he occupied the Museum for one night, together with dozens of extemporaneous participants, to protest against the manipulation and neutralization of art's disruptive power within the context of the contemporary 'art system'. To protect the Museum from the Museum, as he puts it. The very gesture, an occupation, became the content of the intervention, as the very body of the artist and his presence became the message. Thus visibilized were power relations and interests that too often fall unnoticed within the depurated spaces of contemporary art galleries and museums. A sort of performance in itself, the text opens a space which the author occupies, exposing himself, in first person, with defiant and vulnerable words, just as his intervention was defiant and vulnerable. The narration manages to communicate the temporality of the intervention, with the hesitations, enthusiasm, as well as urgency and pressure of its unfolding, a reminder in itself of the urgency and pressure that artists face today. "I entered as an artist, and exited as a person", Mourão writes concluding his piece, leaving unanswered a series of crucial questions that his performance and his text, nonetheless, successfully embodied.

\section{Andrea Pavoni}

\section{Dossier Editor}

